\title{
NOTES ON MIMICRY AND VARIATION
}

\author{
By W. J. Rannbow, F.L S., Entomologist.
}

(Frontispiece.)

Recently there were added to the Australian Museum cabinets specimens of Phonicops porphyropis, Meyr. \& Low., and Milionia queenslandica, Roths. All were obtained from Mr. F. P. Dodd, of Kuranda, N. Queensland. They are particularly interesting from the fact that the former is apparently a mimic of the latter.

The Skipper, P. porphyropis (Front., fig. 1), has dark fuscous wings, suffused with iridescent purple; on the forewing there is a moderately broad transverse bright yellow band, the edges of which are irregularly dentate, whilst on the hindwing, at the termen, and just below the apex, there is a rather narrow patch of yellow. Except in point of size there is no apparent difference between the male and female forms, the latter being somewhat the larger of the two. They are really beantiful insects, and although rare in collections, may nevertheless be fairly prevalent in the deep recesses of the rich tropical jungle of Northern Queensland.

The moth, M. queenslandica (Front., fig. 2), like the butterfly, has dark fuscous wings. The forewings have each a broad, transverse, bright yellow band, the edges of which are uneven; the hinder angle has a somewhat dusky crimson bar, and this terminates in and suffuses the lower extremity of the transverse yellow bar. In some examples the crimson bar is much more vivid than in others. The lower wings are edged and dentated with yellow, and each is further ornamented with a large, irregularly-shaped concolourous spot.

Although obviously distinct from one another, it would nevertheless be an exceedingly difficult matter to differentiate between the two when on the wing and in flight. Our Australian Lepidoptera, although presenting numerous instances of protective colouration, affords very little in the way of true mimicry. For this reason such an instance as the one referred to above is decidedly interesting.

The genus Hypolimnas, Hübn.( = Diadema, Boisd.), is apparently, as pointed out by Wallace, of Austro-Malayan origin. Of the fifteen species and their numerous varieties all, with the excep- 
tion of about five (African), occur within this area. Two, $H$. botina, Liun., and $H$. misippus, Linn., have a wide range, the former occurring on every island in the Malayan Archipelago, as well as India, Australia, and the Pacific Islands, and the latter in Java, Borneo, Lombock, Timor, Celebes, India, Guiana, Australia, and Africa.

"This genus," says Wallace, ${ }^{1}$ " and those which have been separated from it, furnish us with examples of almost all the anomalies of variation. Some species present an amount of variation perhaps greater than any to be found among butterflies; others scarcely vary at all. The sexes are, in some species, absolutely without a feature of their colouration in common; in others they are hardly distinguishable. In a large number of species there is the most wonderful mimicry of other groups, so that they have been mistaken for Danaide and Acrceidee, and there is perhaps nothing more striking than the accurate manner in which some African species imitate the striped and spotted Acrcece, which inhabit the same districts. In the Eastern islands the protective mimicry has sometimes caused the usual sexual characters to be completely reversed, which has led to confusion in the determination of species." The mimicry of Danaus chrysippus, Linn., by Hypolimnas misippus, is not only a wonderful, but a well-known example. The common Danaus (Limnas) petilia, Stoll., is regarded as the Australian form of D. chrysippus. The last-named species occurs in India, Burmah, Malayan Archipelago, Africa, and even Europe.

In respect of the Australian form of Hypolimnas bolina, Linn., the males are very constant in colouration and ornamentation, but the females present an almost unending series of variations, both in size, colour, and ornamentation. The chief feature of interest to the student is that the female is apparently, in a state of flux, the examination of many examples showing a tendency on the part of the insect to conform to the Danaid type.

In our cabinets we have a number of varieties. One, collected some years ago by Mr. G. Masters at, Gayndah, Queensland(Front., fig. 3), measures, in expanse, four inches. It is dark olivaceousbrown, suffused with purple. The forewing has a few small sub-costal spots above the cell; a transverse blue macular fascia beyond the end of the cell; a submarginal series of white spots placed between the nervules, the two uppermost of which are

1 Wallace.-Trans. Ent. Soc. Lond., 1869, p. 278. 
largest and separated from each other by a nervule; beyond the series just described there is a submarginal and marginal series of waved bluish-grey spots, and these vary both in size and in intensity; viewed in different angles the colour of these spots varies, a deep purple being sometimes noted; fringe picked out with patches of white; between the median and first submedian nervules there is a small patch of orange. Hindwings have two submarginal rows of bluish-grey spots between the nervules, those of the inner row being much the smallest and placed singly, whilst those of the outer row are in pairs; a marginal row of more or less obscure concolorous markings lie close to the outer angle; fringe as in forewings. On the underside the wings are of a greyish-brown colour. The forewing has the lower half suffused with ferruginous; the transverse fascia beyond the cell is obscurely greyish; a narrow transverse bar of dark chocolate brown commences near the costal nervure and terminates at the distal extremity of the anal angle; between the costa and the costal nervure there are a number of scattered white scales, whilst just within the cell there are two large patches of white scales, each patch seated upon a dark brown back ground; beyond the cell and just before the transverse grey fascia there is a third patch of white scales, and these are also seated upon a dark back ground; the marginal and submarginal spots coincide in position to those on the upper surface; those nearest the posterior extremity of the anal angle are large and bluish-grey; the intermediate ones are smaller and more or less obscure; the apical pair of the innermost submarginal series are large and oval. On the lower wing there is a faint transverse bar of grey running across the centre of the wing, and this commences with a large roundish grey spot near the middle of the anterior angle; there is a submarginal row of small bluish-grey spots placed singly between the nervules; below these again a row of large, conical greyish markings seated in pairs between the nervules, and below the latter series a waved greyish line interrupted and broken by nervules. All these spots and markings are prominent and distinct on the lower side, whilst on the upper they are obscure.

The next example to which I desire to draw attention comes from the Clarence River, N.S. Wales (Front, fig. 4). It is as large as the preceding example, but is markedly distinct from it. In this form we can trace what appears to be a further step in the process of evolution towards the Danaid type. The blue macular fascia referred to as occurring on the upper wing of the former is in the present example a short but prominent, broken, trans- 
verse bar consisting of four large elliptical white patches; the orange-coloured patch is also more than twice the size of the one in the forewing of the first example; the inner submarginal series of spots, except the apical pair, are very small and white; marginal rows of bluish spots only faintly discernible. On the lower wing, instead of a faint blue transverse fascia there is a large median white patch, the edges of which are suffused with blue ; marginal spots and markings obscure, bluish; cilia of both wings alternately dark brown and white. On the underside the wings agree in general colour with those of the first example, but differ from them by the transverse macular fascia on the forewing being white, and again by a broad transverse white bar running obliquely across the hindwing; the marginal and submarginal patches of white are also much heavier than are those of first example.

A third example (Front., fig. 5) comes from Kensington Downs, Queensland, where with a number of others it was collected by Mr. A. J. Ewen. An examination of these shows a wide range of variation, both in colouration and size. In the form under consideration the upper wings are velvety black; the transverse macular fascia is white, and each of the large spots comprising it is edged with blue; each of the two large apical spots, and the series of small, submarginal spots that proceed from them are also white and faintly edged with blue; the marginal and submarginal markings are distinct though fine; the orange-coloured patch on the lower half of the wing is much larger than that of the second example quoted (Front., fig. 4). The lower wing is velvety black at base, outer and anal angles very dark velvety brown, median area white eảged and faintly suffused with blue, marginal markings indistinct; cilia alternately black and white. On the underside the wings are much darker than in the second example, and this has the effect, naturally, of making the transverse marginal and submarginal white markings, as also the series of small bluish spots, stand more prominently out.

Other examples collected by Mr. Ewen show, in their variation, the same apparent tendency towards mimicry, and in some not only is there present the bright orange-red patch on the upper wing, but the lower wing also bears indications of a gradual evolutionary tendency towards the same colour. Taking the underwings of both sexes of this species into account, there appears to me to be little doubt, that when the insects are at rest, the colouration and markings must be protective, else, considering that the species is decidedly edible to insectivorous animals it could scarcely be so common. We must not forget that its earlier stages may have something to account for in this 
respect. The larvæ are gregarious and "when first produced they are green, with black heads, and are thinly covered with hairs. After the first moult the body is covered with whorls of tubercles, each emitting three or four hairs. The head bears two bristly spines. When full fed, the body becomes throughout of a rich velvety black, with whorls of branched spines of a yellow colour, whilst the two on the head are black. . . . In length the larvæ attains to nearly three inches, and is of a full and plump form. It is extremely handsome in appearance, but of very offensive habits." ${ }^{2}$ Then, again, the pupa, with its abdominal segments armed with stout pointed tubercles, in addition to its colour, which is purple-brown blotched with black on the wing-cases, must also be of advantage in aiding the species in the struggle for existence.

In addition to the preceding forms we have other examplesone from this State and one from Thursday Island, for instancewhich are so distinct that a tyro could scarcely be blamed for regarding them as separate. In the first place they are much smaller; the one from New South Wales has an expanse of rather more than three inches, and the other of only two and threequarters. In size and colour of the wings on their upper side, save for the splash of orange-red on the forewings, they more nearly conform to Danaus (Salatura) affinis, Fab., a species ranging from Clarence River, N.S. Wales, to Cape York and Port Darwin. The ground colour of the Danaid and Satyrid is dull brown, and each has on the forewing an oblique, transverse, white macular fascia, and white apical, marginal and submarginal spots. But it is in the lower wings that the greatest resemblance between the two species exists; each are of the same chocolate-brown and each have a large patch of white. In the Danaid the latter extends right to the anal angle, but in the Satyrid it scarcely reaches it. On the under side the resemblance in colour and markings of $H$. bolina to $D$. affinis is less distinct, but the New South Wales example of the former, owing to its large median area of white, extending as it does to the anal angle, together with its large marginal and submarginal white markings, and its alternating white and brown cilia, is the closest example of the Satyrids to the Danaid insect.

There can be little doubt that the Australian forms of $\mathrm{H}$. bolina, like the Indian butterflies of that species, are affected by the seasons ; that we have in fact "wet" and "dry" season forms, but these seasonal changes have not yet been studied.

${ }^{2}$ Rainbow-A Guide to the Study of Australian Butterflies, 1907, pp. 80 and 81 , fig. 48 . 


\section{$2 \mathrm{BHL}$ Biodiversity Heritage Library}

Rainbow, W J. 1908. "Notes on mimicry and variation." Records of the Australian Museum 7, 69-73. https://doi.org/10.3853/j.0067-1975.7.1908.953.

View This Item Online: https://www.biodiversitylibrary.org/item/33721

DOI: https://doi.org/10.3853/j.0067-1975.7.1908.953

Permalink: https://www.biodiversitylibrary.org/partpdf/17643

\section{Holding Institution}

MBLWHOI Library

\section{Sponsored by}

MBLWHOI Library

\section{Copyright \& Reuse}

Copyright Status: NOT_IN_COPYRIGHT

This document was created from content at the Biodiversity Heritage Library, the world's largest open access digital library for biodiversity literature and archives. Visit BHL at https://www.biodiversitylibrary.org. 